\title{
ICT and IT Initiatives in Public Governance - Benchmarking and Insights from Ethiopia
}

\author{
Premkumar Balaraman
}

Department of Management Studies, Adigrat University, Ethiopia

\begin{abstract}
Aim: The paper mainly aims to identify Benchmark Practices of ICT and IT initiatives in Public Governance, Specifically the Case of India and others. Also it attempts to describe the status quo of ICT and IT initiatives in Public Governance in Ethiopia and assess the impact of ICT / IT initiatives on Public Sector Reforms.
\end{abstract}

Research Methodology: To assess the Global practices of ICT and IT enabled Public Governance the paper has adopted descriptive and qualitative approach. To describe the status quo of ICT and IT initiatives in Public Governance in Ethiopia and assess the impact of ICT / IT initiatives on Public Sector Reforms a mixed mode approach is adopted using secondary data (literature), qualitative and quantitative data. 15 Face-face In-Depth Interviews were conducted over a time period of 6 weeks, with various stakeholders of Public Governance with open ended questions on ICT / IT initiatives and public sector reforms in Ethiopia. In addition, a quantitative study using questionnaire (Sample size $=412$, Cronbach's $\alpha=0.565$ ) was also conducted by convenient sampling.

Findings: Some of the innovative ICT /IT based Global Benchmark E-Governance Services includes, EEmployment Services, GIS based Emergency Assistance, Integrated Social Assistance System, Open government data, etc. The face-face in depth interviews revealed major issues like high levels of Corruption, non-transparency, lack of skilled manpower in ICT/IT domain, low levels of literacy, cultural and language barriers, etc. In the evolved linear regression model from the questionnaire survey, it indicates that the model best explains the impact of ICT/IT initiatives (Independent variable) on the Public sector reforms (dependent variable) by nearly $50 \%$. $(\mathrm{R}=.701, \mathrm{R}$ Square $=0.492, \mathrm{~F}=65.387, \mathrm{Sig}=.000)$.

Keywords: Benchmark, ICT/IT initiatives, Public Sector Reforms.

JEL Classification: H83, D73.

(C) The Author, 2018. This article is published with open access at Sumy State University.

\subsection{Introduction}

ICT and IT based initiatives like Public Information Systems, Online Delivery of Citizen Services using Websites \& Mobile Applications, etc. are widely used in developed and developing countries to enable the participation of citizens in policy making, democratic participation and delivery of Government Services with Transparency, Accountability, Efficiency and Speed. Briefly in the understanding of Management Literature ICT and IT based initiatives are broadly referred under the umbrella of E-Government and E-Governance interchangeably. Though such Electronic or ICT / IT means of tools are widely used in private sector for Business process reengineering, Information Systems based Management and Enterprise Resource planning domains, similar approaches for performance and efficiency based approaches for public sector needs started initially in the 1980s with the development of basic Information Systems based public sector services, Records Management and which gradually scaled up with the evolution of Internet based Technologies.

In this context of Public Governance Evolution and its Reforms, there have been significant trends and approaches in the developed countries and started to be replicated in developing countries in Asia, Africa and other continents, and specifically the paper considers the Case of Ethiopia.

\subsection{Objective of the Study}

To Identify Benchmark Practices of ICT and IT initiatives in Public Governance, Specifically the Case of India and others.

To describe the status quo of ICT and IT initiatives in Public Governance in Ethiopia and assess the impact of ICT / IT initiatives on Public Sector Reforms. 


\subsection{Trends in Pubic Governance and ICT /IT initiatives}

The Forthcoming section clarifies the various aspects on Public Governance, its evolution and traces back from the initial proposition of efficiency and entrepreneurial spirit based public governance in 1980s till the evolution of current day status of ICT and IT based Public Governance Systems. Governments converged substantially over period 1990-2005, introducing fiscal austerity measure and making substantive changes to public sector management and operation (Peters, 2012: 208) through privatization, marketization, and publicprivate partnerships.

Public Administration Reform (PAR) can be very comprehensive and include process changes in areas such as organizational structures, decentralization, personnel management, public finance, results-based management, regulatory reforms etc. In line with UNDP's approach to Democratic Governance, some of the complex elements of PAR include decentralization, anti-corruption, E-governance and access to information. Other important issues in least developed countries include Public Administration in Crisis Countries, the Impact of HIV/AIDS on Public Administration in Worst Affected Countries, Gender Mainstreaming in Public Administration Reform and others.

New Public Management - (NPM): New Public Management is the label, which many academics have given to a series of re- forms from the 1980s onwards, to improve the efficiency and performance (Pollitt, Thiel, \& Homburg, 2007: 1, Vries and Nemec, 2013: 4) of western governments and/or public sector organizations. Examples are the development of performance indicators and benchmarking, personnel reforms aimed at 'normalizing' public sector employment on private sector models, placing executive bodies at arms' length from ministries, establishing public private partnerships and introducing new management techniques and instruments.

New Public Governance - (NPG): In this mode of New Public Governance, Practitioners are using new quasi-legislative and quasi-judicial governance processes, including deliberative democracy, e-democracy, public conversations, participatory budgeting, citizen juries, study circles, collaborative policy making, and alternative dispute resolution, to permit citizens and stakeholders to actively participate in the work of government (Bingham, Nabatchi, \& O'Leary, 2005: 547).

E-Government: "E-government is defined as utilizing the Internet and the world-wide-web for delivering government information and services to citizens." While definitions of e-government by various sources may vary widely, there is a common theme. E-government involves using information technology, and especially the Internet, to improve the delivery of government services to citizens, businesses, and other government agencies (Clift, 2003).

E - Governance: E-Governance is generally considered as a wider concept than e-government, since it can bring about a change in the way citizens relate to governments and to each other. E-governance is defined as the, "application of electronic means in (1) the interaction between government and citizens and government and businesses, as well as (2) in internal government operations to simplify and improve democratic, government and business aspects of Governance" (Backus, 2001).

Pubic Value Governance - (PVG): This is a new public administration movement is emerging to move beyond traditional public administration and New Public Management (Bryson, Crosby \& Bloomberg, 2014: 445). Government has a special role to play as a guarantor of public values, but citizens as well as businesses and nonprofit organizations also are important as active public problem solvers.

\subsection{Need for ICT / IT enabled Public Governance}

From Literature on Public Governance and IT based initiatives in developed countries and developing countries, there is empirical evidence on major benefits of such initiatives on improved public services, citizen interaction, participation of various stakeholders of Governance, better decision making, transparency and people centric democracy. In Uganda, public sector reforms and E Government initiatives (Guma, 2013: 240) have led to contemporary practices in Governance resulting in efficient and effective administration of Government systems.

Of the various forms of public sector reforms, financial accountability and reduction of corruptive practices in Governance has been the focus in public sector reforms especially in developed countries. Good governance is often regarded as essential for a country's economic development. The World Bank has encouraged the use of decentralized decision making and private sector participation to achieve greater efficiency, transparency and accountability in the delivery of social and infrastructural services (Kulshreshtha, 2008: 556). Electronic 
service implementation (ESI) in the public sector attempts to improve efficiency, effectiveness, and transparency of governmental departments. Despite having provided the necessary infrastructure and investment, many governments have struggled to realise such aims due to the various forces that challenge implementation and institutionalization (El-Haddadeh, Weerakkody and Al-Shafi, 2013: 135).

\subsection{Conceptual Frameworks on ICT / IT based Public Governance}

1.4.1 EXPGOV Framework: The contemporary trend in E-Governance Systems is that, Interoperability (Misuraca, Alfano \& Viscusi, 2011: 95) is predominantly seen as a means to enable public administrations to collaborate within Members State and across borders. And the case of E-Governance implementations in developing countries in Africa, Asia is no exception from this aspect of interoperability. Based on the study of the EXPGOV project in assessing the interplay between ICTs (service innovations in European Cities) and governance processes at city level it is found that three main value drivers constitute the basis of a theoretical framework for ICT-enabled governance at the local level (city level). The EXPGOV project's value drivers are (European Commission, 2010): Performance: this includes effectiveness and efficiency; Openness: this includes access to information as a proxy for participation, transparency and accountability that also serves the goal of ensuring consensus orientation (following democratic practices); Inclusion: this includes equity and inclusiveness.

\subsubsection{Osborne's 3 Stage Model of Public Sector Reform}

According to Helen (2016: 41), Networked forms of governance is largely equated with the move towards what Osborne (2006: 277) refers to as new public governance, which has a strong focus on collaboration and horizontal ties between individuals and agencies.

\subsubsection{Other Frameworks on E-Governance}

Zwahr, Finger and Mueller (2005: 9) provided two perspective of E-Governance namely, Macro Perspective which consists of variables like institution of governance, functions of state and impact of ICT. Under the micro perspective, three traditional functions of state were identified as shaping of the political process, the regulation of the behavior of the various actors (government policies), and the provision of specific public services.

Ebrahim and Irani (2005: 589) presented E-government architecture framework with four layers: Access layer: Involves the channels that users can access for availing various government services, E-government layer: This layer is about integrating digital data of various organizations into a web-portal of government services, in the form of a one-stop e-government portal, E-business layer: This layer is focused on using ICT applications and tools to harness a networks of trust, knowledge sharing and information processing that takes place both within and between organizations, Infrastructure layer: This layer focuses on technologies that should be in place before egovernment services can be offered reliably and effectively to the public.

\subsection{ICT / IT based initiatives and Public Governance in Ethiopia}

The latest E-Government Survey of United Nations (UNDESA, 2014),' commended Ethiopia for the progress made in E-Government Development Index (EGDI). In general, Ethiopia received (between 0.25 and 0.50 ) which is a middle-level EGDI point. In terms of OSI- Online Service Index, Ethiopia received 0.4567 and was ranked $72^{\text {nd }}$ among 183 nations around the world. The report shows that Ethiopia is among the best performer among the 31 Landlocked Developing Countries (LLDCs) among the United Nations Member States.

\subsubsection{ICT Policy and Strategy of Ethiopia}

The Ethiopian ICT policy (MCIT Ethiopia, 2011) covers knowledge and information as a tool for development \& ICT as a sector or industry. Apart from being as enabler of socioeconomic development, ICT also supports Ethiopia's on-going process of democratization and good governance. The Ethiopian e-government strategy (MCIT Ethiopia et.al.) that was approved in 2011 envisages the implementation of 219 e-services comprising of 79 informational and 140 transactional services over a five-year period. Implementation is proposed through 12 priority projects and service delivery would be through four primary channels-Portals, Call centres, Mobile devices and Common service centres.

The Ethiopian E-Government Strategy has been designed keeping the following guiding principles (MCIT Ethiopia et al.), namely creating SMART (Simple Moral Accountable, Responsive and Transparent) Government, promote causes of e-citizen and e-democracy, transformation process, capacity building, 
integration, citizen centric, multi-channel delivery, information access to all, enable participation of all, inclusion of private sector in public service delivery, etc.

The e-government service delivery will be facilitated and strengthened through six core projects, including, The National Payment Gateway, The Enterprise Architecture framework, The Public Key Infrastructure, The National Data Set, The National Enterprise Service Bus and The National Integrated Authentication Framework.

In addition, common applications that horizontally cut across all ministries are proposed. These include initiatives like E-Procurement, Human resource Management System, E-Office, E-Mail and Financial Management Information System.

\subsubsection{Various ICT / IT based E-Governance Initiatives in Ethiopia}

The major ICT Initiatives in Ethiopia can be divided into infrastructure, application, Standards/Guidelines and HRD (United Nations, 2011). The Table 1 in the forthcoming section throws light on the major ICT initiatives and their major focus for better clarity on ICT based public governance reforms in Ethiopia.

Table 1. ICT / IT based initiatives for public governance reforms in Ethiopia

\begin{tabular}{|c|c|c|}
\hline $\begin{array}{c}\text { S } \\
\text { No } \\
\end{array}$ & ICT Initiative & Focus Areas \\
\hline 1 & Infrastructure & $\begin{array}{l}\text { a) Increase Telecom infrastructure connectivity, National Data Center (DC), Regional DC, } \\
\text { b) WoredaNet (provide ICT services such as video conferencing, directory, messaging, and VoIP and } \\
\text { Internet at the federal, regional and lowest level of government, build transparent \& accountable } \\
\text { government system, citizen participation), } \\
\text { c) SchoolNet (Give internet and digital content online to connected schools), } \\
\text { d) EtHERNet - Ethiopian Educational and Research Network (Resource sharing, Video conferencing, } \\
\text { E-Library \& shared digital content), } \\
\text { e) AgriNet - Agro information sharing and repository } \\
\text { f) Management and security of the Infrastructure (like NOC), Acquiring different capacity servers, } \\
\text { computers, } \\
\text { g) } 13 \text { ministries and } 19 \text { agencies/offices connected to the WoredaNet, } \\
\text { h) Call Center - Provide up-to-date and accurate information on government services (Registered } \\
\text { Government Institutions: Federal/AA level Institutions (Transport Authority, Addis Ababa Transport } \\
\text { Branch Office, Document Authentication and Registration Office, Social Security Agency, Addis } \\
\text { Ababa city Land Administration and Building Permit Authority, National Archives and Library } \\
\text { Agency, Ministry of Agriculture), Oromia Regional Offices }\end{array}$ \\
\hline 2 & Applications & $\begin{array}{l}\text { a) To automate the back-office activities (most are web-based), } \\
\text { b) Prioritized and initiated by Ministries and Agencies to undergo the Business Process Re- } \\
\text { Engineering (BPR) } \\
\text { c) Major activities are: Government Portal, Justice Information System, Drivers \& Vehicles } \\
\text { Management Information System, National Records \& Library Management Information System, HR } \\
\text { Information System, Trade Registry System, Exam \& Placement System, etc. } \\
\text { d) M-Government using SMS (on process): To give SMS based G2C services (3 organization and } \\
\text { services covered are: - EEPCO: -Electricity Bill Information, NBE: - Exchange Rates Information, } \\
\text { National Exam: - Student Result Information) }\end{array}$ \\
\hline 3 & $\begin{array}{l}\text { Policy, Standards, } \\
\text { Guidelines }\end{array}$ & $\begin{array}{l}\text { ICT Policy (country level), Localization of ICT Terminologies, Keyboard Standard, National Disaster } \\
\text { Prevention \& Recovery Plan, Procedure and Guideline, E-Government Strategy, PKI (Public Key } \\
\text { Infrastructure), EA (Enterprise Architecture,) }\end{array}$ \\
\hline 4 & HRD & National ICT HRD Strategy, R\&D Strategy and Guideline, \\
\hline
\end{tabular}

\subsection{Conceptual Framework \& Data Presentation}

ICT and IT initiatives in Public Governance is considered in the paper as the focal point of Study, and revolves around the evolution of the concept (Fig.1 / Table 2) of Public Administrative Reforms (PAR), which by itself emanates from the levels of PAR evolution starting from E-Governance / E Government (in the Beginning 1980s), New Public Management and New Public Governance (Vries and Nemec, (2013); Bingham, Nabatchi, \& O'Leary, (2005)).

Hence in this paper, the Dependent Variable - Public Sector (Administrative) Reform is measured by the grouping of sub concepts like Corruption Level (Decreased) in Public Sector Utilities \& Services; Level of Transparency in Public Governance, Public Spending, Poverty Reduction, Welfare; Level of Citizen Participation in Public Governance, Policy Making.

The Independent Variables Namely Citizen Awareness Level on the various ICT \& IT initiatives of Public Governance (In the Case of Ethiopia) are considered to enable Total Public Sector (Administrative) Reform. 
In addition, questions pertaining to Innovative IT and ICT enabled Public Governance Solutions, Reach of Internet and Mobile Connectivity (Backbone / Infrastructural Requirement) and others are also included in the questionnaire instrument to augment the study. Awareness of the Citizens on the various ICT \& IT initiatives of Public Governance indirectly means the availability of such initiatives in Ethiopian Context.

From the Descriptive Statistics (Table 3), it is inferred that, most of the demographic variables like Age, Gender and Locality revolves around the midpoint value of the total range, namely the mean, and hence the survey necessarily covers all categories in the sample to be representative of the population studied. Also from the various Independent Variables of the study, Awareness (Availability) of ICT / IT Based Common/Rural Service Centres like Post office (Mean = 4.46, S.D = 0.729), Agri Information, Awareness (Availability) of Government ICT / IT Based Greetings Facilities, Information transparency by SMS, Email (Mean = 4.35, S.D $=0.507$ ) appear to have strong influence on the Dependent Variable based on the magnitude of the Mean.

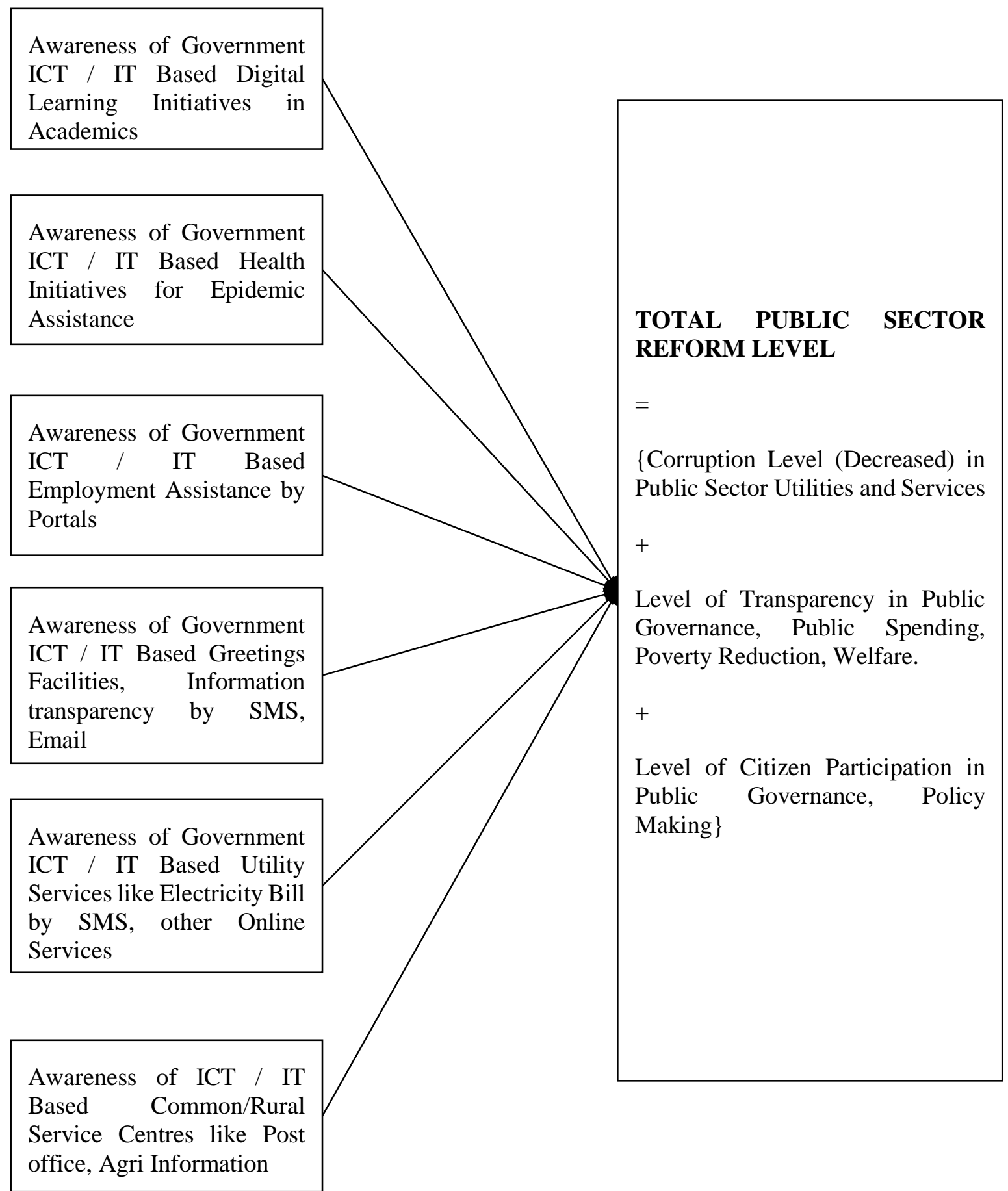

Independent Variable

Dependent Variable

Figure 1. Conceptual Framework (Adapted from: Vries and Nemec, (2013); Bingham, Nabatchi, \& O'Leary, (2005)) 
Table 2. Variable Definitions and Data Sources

\begin{tabular}{|c|c|}
\hline Independent Variable & Definition / Description \\
\hline $\begin{array}{l}\text { Awareness (Availability) of Government ICT / IT Based } \\
\text { Digital Learning Initiatives in Academics }\end{array}$ & $\begin{array}{l}\text { Enables Information Dissemination, Empowerment, } \\
\text { Learning and Welfare of Public, Poverty Reduction. }\end{array}$ \\
\hline $\begin{array}{l}\text { Awareness (Availability) of Government ICT / IT Based } \\
\text { Health Initiatives for Epidemic Assistance }\end{array}$ & $\begin{array}{l}\text { Enables Information Dissemination, Learning and Welfare } \\
\text { of Public. }\end{array}$ \\
\hline $\begin{array}{l}\text { Awareness of Government ICT / IT Based Employment } \\
\text { Assistance by Portals }\end{array}$ & $\begin{array}{l}\text { Enables Information Dissemination, Empowerment, } \\
\text { Learning, Welfare of Public, Poverty Reduction. }\end{array}$ \\
\hline $\begin{array}{l}\text { Awareness (Availability) of Government ICT / IT Based } \\
\text { Greetings Facilities, Information transparency by SMS, } \\
\text { Email }\end{array}$ & $\begin{array}{l}\text { Enables Information Dissemination, Empowerment, } \\
\text { Transparency, Corruption Reduction / Prevention, Public } \\
\text { Participation }\end{array}$ \\
\hline $\begin{array}{l}\text { Awareness (Availability) of Government ICT / IT Based } \\
\text { Utility Services like Electricity Bill by SMS, other Online } \\
\text { Services }\end{array}$ & $\begin{array}{l}\text { Enables Information Dissemination, Empowerment, } \\
\text { Transparency, Corruption Reduction / Prevention, Public } \\
\text { Participation, Policy Making }\end{array}$ \\
\hline $\begin{array}{l}\text { Awareness (Availability) of ICT / IT Based Common/Rural } \\
\text { Service Centres like Post office, Agri Information }\end{array}$ & $\begin{array}{l}\text { Enables Information Dissemination, Empowerment, } \\
\text { Learning, Welfare of Public, Poverty Reduction. }\end{array}$ \\
\hline \multicolumn{2}{|l|}{ Dependent Variable } \\
\hline $\begin{array}{l}\text { TOTAL PUBLIC SECTOR (ADMINISTRATIVE) } \\
\text { REFORM LEVEL - (PAR) }\end{array}$ & $\begin{array}{l}\text { \{Corruption Level (Decreased) in Public Sector Utilities and } \\
\text { Services + Level of Transparency in Public Governance, } \\
\text { Public Spending, Poverty Reduction, Welfare. + Level of } \\
\text { Citizen Participation in Public Governance, Policy Making\} }\end{array}$ \\
\hline Data Collection Technique & DATA SOURCE \\
\hline Questionnaire & Primary \\
\hline Face-face In-Depth Interviews & Primary \\
\hline Literature Review & Secondary \\
\hline
\end{tabular}

Table 3. Descriptive Statistics

\begin{tabular}{|c|c|c|c|c|c|}
\hline \multicolumn{6}{|c|}{ Descriptive Statistics } \\
\hline & $\mathrm{N}$ & Min & Max & Mean & Std. Deviation \\
\hline Age in Years & 412 & 1 & 5 & 2.47 & 1.249 \\
\hline Gender & 412 & 1 & 2 & 1.49 & .501 \\
\hline Locality & 412 & 1 & 4 & 2.24 & .986 \\
\hline Income Level per Month & 412 & 1 & 5 & 2.22 & 1.068 \\
\hline $\begin{array}{l}\text { Awareness of Government ICT Based Digital Learning Initiatives } \\
\text { in Academics }\end{array}$ & 412 & 1 & 4 & 2.07 & 1.003 \\
\hline $\begin{array}{l}\text { Awareness of Government ICT Based Health Initiatives for } \\
\text { Epidemic Assistance }\end{array}$ & 412 & 1 & 5 & 2.17 & .923 \\
\hline $\begin{array}{l}\text { Awareness of Government ICT Based Employment Assistance by } \\
\text { Portals }\end{array}$ & 412 & 1 & 4 & 1.88 & .968 \\
\hline $\begin{array}{l}\text { Awareness of Government ICT Based Greetings Facilities by } \\
\text { SMS, Email }\end{array}$ & 412 & 3 & 5 & 4.35 & .507 \\
\hline $\begin{array}{l}\text { Awareness of Government ICT Based Utility Services like } \\
\text { Electricity Bill by SMS }\end{array}$ & 412 & 1 & 5 & 4.04 & .985 \\
\hline $\begin{array}{l}\text { Awareness of ICT Based Common/Rural Service Centres like } \\
\text { Post office, Agri Information }\end{array}$ & 412 & 2 & 5 & 4.46 & .729 \\
\hline Total Public Sector Reform Level & 412 & 3.00 & 9.00 & 5.6723 & 1.26411 \\
\hline Valid N (listwise) & 412 & & & & \\
\hline
\end{tabular}

\subsection{Research Methodology}

To assess the Global practices of ICT and IT enabled Public Governance the paper has adopted descriptive and qualitative approach. To describe the status quo of ICT and IT initiatives in Public Governance in Ethiopia and assess the impact of ICT / IT initiatives on Public Sector Reforms a mixed mode approach is adopted using secondary data (literature), qualitative and quantitative data.

15 Face-face In-Depth Interviews were conducted over a time period of 6 weeks, with various stakeholders (Public Sector Experts, Bureaucrats, IT Experts and Citizens or End-users) of Public Governance with open ended questions on ICT / IT initiatives and public sector reforms in Ethiopia. In addition, a quantitative study using questionnaire (Sample size $=412$, Cronbach's $\alpha=0.565$ ) was also conducted by convenient sampling. Five point Likert Scale is utilized in the design of the Customized Questionnaire Instrument.

\subsection{Data Analysis Methods}

To assess the Global practices of ICT and IT enabled Public Governance the paper has adopted descriptive and qualitative approach mainly drawing insights from secondary sources of data like literature on E- 
Governance and Public Governance Reforms. Major World Class E-Governance initiatives are identified from the top ranked countries with high maturity level in leadership and implementation of ICT and IT enabled Public Governance Services.

The present study uses Basic Descriptive Statistics (Mean, S.D, Max, Min- To explore the most significant ICT / IT initiatives based on the Magnitude and Deviation), Chi-Square Tests / Bar Chart (Test of Dependency Between Gender / Locality on the Choice of Most preferred ICT / IT initiatives), ANOVA (To measure the most significant and successful ICT / IT initiative and Regression Analysis (To measure the Impact of ICT / IT initiatives - Independent Variables on Public Sector Reforms - Dependent Variable in the Case of Ethiopia respectively.

Appropriate themes were identified in summarizing the interviews and triangulation of the various methods including primary and secondary data on ICT / IT based Public Governance confirms the different facts and gaps in the reforms needed. The questionnaire data was analyzed using IBM SPSS version 20.0 and statistical tests like Chi-Square, ANOVA and Linear Regression were utilized for Hypothesis Testing.

The forthcoming section presents a snap shot view of the various important Statistical tools utilized in the study for better understanding and relevance of applying these techniques for the undertaken research study (Field, 2009).

\subsubsection{Chi-Square Test}

The Chi-square test is one of the simplest and most widely used non-parametric tests in statistical work. The symbol $\chi^{2}$ is the Greek letter Chi. This test is used as a test of goodness of fit. Chi-square can be used in normal distribution as a test of independence. Test is done whether two or more attributes are associated (G.C. Beri, 2008). This test gives the magnitude of discrepancy between theory and observation.

\subsubsection{ANOVA}

One independent variable experiment is called one-way ANOVA. ANOVA stands for Analysis of Variance, the generic name given to a set of techniques for studying the cause and effect of one or more factors on a single dependent variable. Analysis of Variance technique is used when the independent variables are of nominal scale (categorical) and the dependent variable is metric (continuous), or at least interval scaled (Nargundkar, 2003).

The ANOVA technique focuses on the behavior of the variance within a set of data. In measures of dispersion, the variance of a variable is equal to the average squared deviation from the mean of the variable. The logic of the ANOVA technique says that if we calculate the variance between the groups and compare it with the variance within the groups. It makes a rational determination as to whether the means are significantly different (Hair et al., 2006).

It is a useful technique concerning researches in the fields of economics, education, business, and in other disciplines. This technique is used when multiple samples cases are involved. The significance of the difference between the means of two samples can be found out through $\mathrm{Z}$ test or $\mathrm{t}$ test, but the problem arises when it happens to examine the significance of difference amongst more than two sample means at the same time.

\section{Basic principles of analysis of variance (ANOVA)}

The basic principle is to test for difference among the means of the populations by examining the amount of variation within each of these samples, relative to the amount of variation between the samples. In terms of variation within the given population, it is assumed that the values of $\left(X_{\mathrm{ij}}\right)$ differs from the mean of this population only because of random effects, i.e., there are influences $\left(X_{i j}\right)$ which are unexplainable, whereas in examining differences between populations. It is assumed that the difference between the mean of the $\mathrm{j}^{\text {th }}$ population and the grand mean is attributable to what is called a "specific factor" or what is technically described as treatment effect. Thus, while using ANOVA. It is assumed that each of the samples is drawn from a normal population ant that each of these populations has the same variance. It is also assumed that all factors other than the one or more being tested are effectively controlled.

\section{The 'F' test - (Variance Ratio Test)}

The "F"-test is named in honour of the great statistician R. A. Fisher. It is used to find out whether the two independent estimates of population variance differ significantly. 


\subsubsection{Regression Analysis}

A regression analysis is used to investigate the overall strength of the association or relationship in detail. A bivariate regression analysis is a statistical technique that users information about the relationship between an independent or predictor variable and a dependent or criterion variable and combines it with the algebraic formula for a straight line to make predictions. A fundamental basis of regression analysis is the assumption of a straight line relationship between the independent and dependent variables.

In applying regression analysis, we examine the relationship between the independent variable $X$ and the dependent variable $Y$. After computing the values of a and $b$, statistical significance test has to be done. The calculated a (intercept) - $\alpha$ and $b$ (slope) - $\beta$ are sample estimate of the true population parameters. The t-test is used to determine whether the computed intercept and slope are significantly different from zero. a is referred to as a $(\alpha)$ constant and the $\mathrm{b}(\beta)$ is associated with each independent variable. Bivariate regression analysis is used when there is one independent variable and one dependent variable.

Whereas multiple regression analysis is used when there are several independent variables and one dependent variable. The regression analysis shows $\mathrm{R}$ square figures, which show the percentage of variation in one variable that is accounted for by another variable. The standard error of the estimate is a measure of the accuracy of the prediction of the regression equation from the ANOVA table and the F ratio is the result of comparing the account of explained variance to the unexplained variance. The co-efficient table shows the regression co-efficient which is an indicator of the importance of independent variable in predicting a dependent variable. Once the statistical significance of the regression co-efficient is determined the relationship with the variables is identified.

\subsection{Findings and Discussion}

\subsection{Benchmark ICT and IT Initiatives in Public Governance}

The Forthcoming section indicates some of the novel and innovative ICT / IT initiatives in Public Governance towards sustainable development in Global context. Also the same insights can be taken forward for the upcoming countries in Asia, Africa and Ethiopia in particular. Out of the various key benchmark E-Governance Applications (UNDESA, 2016), the major 5 services with high impact on public governance reforms are:

1. E-Employment Services: Malaysian Electronic Labor Exchange, the Egyptian joint government jobs portal, the Italian Employment Information System and the European Employment Service (EURES).

2. Creating new models to engage people through media and GIS / OSM based community mapping: In Dar Es Salaam, Tanzania, location of flood prone homes was gathered for a community mapping exercise through OpenStreetMap (OSM) technologies and helped in the response to the Cholera outbreak by identifying the affected areas, locating victims, and providing critically important information about water points and sanitation.

3. Integrated Social Assistance System (ISASS) - (Turkey): G2G e-government system, all social assistance processes ranging from applications to payments can be carried out in an electronic platform)

4. Initiatives of open government data: Beijing's open government data contains over 400 datasets, including tourism, education, transportation, land use zoning and medical treatment. The website also provides a special "APP" column where people can use such data.

5. ICT-based land registry and management system (BHOOMI, India): Electronic integration of the registration department with land-acquiring bodies, banks and other financial institutions.

\subsection{Case Insights of ICT and IT Applied Public Governance from Asia (India)}

From the Asian Context, the paper takes into consideration India's ICT initiative for Public Governance named as Digital India as a benchmark. The forthcoming section discusses some of the important aspects and benefits of this ICT and IT based initiative, and that can be taken forward for the Governance areas applicable for African context.

The Vision of Digital India Programme is to transform India into a digitally empowered society and knowledge economy. Though in Indian scenario, many of the E-Government initiatives were started in the early 1990s aimed at better Governance and Rural Development, some of the ICT based governance schemes applicable 
for citizen were lagging behind due to many hurdles in implementation, due to lack of government support, non-scalable technology and ownership issues (Kannabiran et al, 2008: 1).

In Contrast the current Digital India Program aims at new schemes as well as pulling existing schemes with re-structuring, revamping and re focus and synchronization with all schemes. The Digital India Program facilitates Collaborative and participative governance of various stake holders. The Weblink http://mygov.in/ is the digital platform of India for participative governance. The main highlight of the various schemes is that it is time bound and to be implemented within 3 years' deadline, and already many in completion and operational stages.

\subsubsection{Pillars of Digital India ICT Initiative for Enhanced Public Governance and Reforms}

There are nine main pillars of Digital India initiative (Digital India, 2015) and the Department of Electronics and Information Technology (DeitY), of India is the nodal agency for overall coordination, and each of these nine pillars are complex and cuts across multiple ministries and departments. The Table 4 below summarizes the main focus of the nine pillars of Digital India initiative for better clarity.

Table 4. Nine Pillars of Digital India - ICT initiative and their focus areas

\begin{tabular}{|c|c|c|}
\hline S.No. & ICT Pillar & $\begin{array}{l}\text { Focus areas and outcome } \\
\end{array}$ \\
\hline 1 & $\begin{array}{l}\text { Broadband } \\
\text { Highways }\end{array}$ & $\begin{array}{l}\text { It consists of three components - a) Broadband all Rural - Integration of Villages under National } \\
\text { Fiber Optic Network., b) Broadband for all - Urban - Leveraging of Virtual Network Operators for } \\
\text { Service Delivery and Communication, c) Integration of Network and Cloud Infrastructure Platform } \\
\text { starting from various Government Departments up to the last service delivery point namely villages. }\end{array}$ \\
\hline 2 & $\begin{array}{l}\text { Universal } \\
\text { Access to } \\
\text { Mobile } \\
\text { Connectivity }\end{array}$ & $\begin{array}{l}\text { Aims at Mobile coverage in phased manner especially in uncovered locations like North East (Hilly } \\
\text { region) India. }\end{array}$ \\
\hline 3 & $\begin{array}{l}\text { Public Internet } \\
\text { Access } \\
\text { Programme }\end{array}$ & $\begin{array}{l}\text { Consists of } 2 \text { sub components - a) Common Service Centres (CSCs) - Multifunctional end points for } \\
\text { delivery of Government and business services in each village administrative office (Village } \\
\text { panchayat), b) Post offices as multi-service centres. }\end{array}$ \\
\hline 4 & E-Governance & $\begin{array}{l}\text { Aims at Government Process Re-engineering (all Ministries and Departments), The Guiding } \\
\text { principles are Simplification and field reduction (Simple, user friendly and minimum information } \\
\text { collection), Online applications and tracking, Online Repositories (Certificates, identity documents, } \\
\text { etc.), Integration of Services and Platforms, Data sharing - Application Programming Interface (API) } \\
\text { and middleware such as National and Service delivery gateways. }\end{array}$ \\
\hline 5 & E-Kranti & $\begin{array}{l}\text { Enhancement and transformation of various mission mode e-governance projects using technology } \\
\text { and re-engineering approach. (using cloud, enable service delivery in mobile to ensure last mile } \\
\text { connectivity, mandating standard and protocols, language localization, leveraging GIS, Security and } \\
\text { electronic data preservation, etc.. }\end{array}$ \\
\hline 6 & $\begin{array}{l}\text { Information } \\
\text { for All }\end{array}$ & $\begin{array}{l}\text { Delivers Open data platform (User / Citizens can access datasets in open format by the ministries / } \\
\text { departments for use, reuse and redistribution), Engage citizens through social media for interaction } \\
\text { and idea collaboration (Mygov.in), Online Messaging of citizens using Email / SMS on special } \\
\text { occasions. }\end{array}$ \\
\hline 7 & $\begin{array}{l}\text { Electronics } \\
\text { Manufacturing }\end{array}$ & $\begin{array}{l}\text { Aims at NET ZERO imports of Electronic goods by 2020. And this goal is confronted by incentives } \\
\text { for Electronic investments, economies of scale, Big ticket items - Fab Less design, set top boxes, } \\
\text { VSATs, Mobiles, Consumer Electronics and Medical electronics, Smart energy meters, smart cards, } \\
\text { micro-ATMS, incubators, Clusters, skill development, R\&D, Branding, Safety standards, Security } \\
\text { forces, National centers, etc.... }\end{array}$ \\
\hline 8 & IT for Jobs & $\begin{array}{l}\text { Focuses on providing training to Youth in IT/ITES Skills for grabbing employment opportunities. } \\
\text { Also aims at coverage of ITES / BPO industry promotion area in uncovered / distant areas like North } \\
\text { East India. }\end{array}$ \\
\hline 9 & $\begin{array}{l}\text { Early Harvest } \\
\text { Programme }\end{array}$ & $\begin{array}{l}\text { Focuses short timeline projects - IT Platform for Messages, E-Greetings, Biometric attendance, Wi- } \\
\text { Fi in all universities, Secure Email in Government, Standardize Government Email Design, Public } \\
\text { Wi-Fi hotspots, EBooks, SMS based alerts, National Portal for Lost and Found Children. }\end{array}$ \\
\hline
\end{tabular}

\subsubsection{Digital India Services}

From the application and benefit perspective of ICT initiatives for better public governance, a glance at the various citizen centric services of the Digital India initiative would serve the purpose as a benchmark. From the various E-Service initiatives the most promising and successful in citizen benefit are AADHAR (unique citizen ID system in India), National Career Service Portal (Portal facilitates registration of job seekers, job providers, skill providers, career counselors), m-KISAN (SMS Portal for timely delivery and dissemination of Farmer information), Passport Seva Project (Enables Simple, efficient and transparent processes for delivery of passport and related services, SWAYAM (Enables access to courses taught from Class 9 till Post graduation 
by anyone, E-Hospital (Is an Open Source Health Information Management System (HMIS), UTS App (Official Android Mobile Ticketing App of Indian Railway for paperless journey), etc.

\subsection{Case Insights of ICT and IT Applied Public Governance from Europe}

\subsubsection{Public Service Reform Plan and ICT based E-Government initiatives of Ireland}

The Public Service Reform Plan of Ireland (European Union, 2016), addresses a wide range of issues such as:

$>$ Implementation of shared services models for HR, payroll, pensions etc.;

$>$ Evaluation of new business models for the delivery of non-core services;

$>$ Reform of public procurement processes and property rationalization; and

$>$ Reducing costs, addressing duplication and eliminating waste to support job creation.

Similarly, to augment the reforms, The Public Service ICT Strategy of Ireland sets out a high-level vision to reinforce ICT's role in supporting Public Service Reform and transformation. It identifies a number of key strategic objectives that will set the future direction for innovation and excellence in ICT within the Public Service.

\subsubsection{Legislations pertaining to ICT and IT based E-Governance and public governance reforms in Europe (Ireland)}

Some of the key legislations pertaining to E-Government strategy in Ireland include Data-Sharing and Governance Bill, (2015), Freedom of Information Act, (2014), Data Protection Act of (1988) / Amended in 2003, Electronic Commerce Act (2000) - eSignatures Legislation / e-commerce Legislation, Communications Regulation Act (2002) and eProcurement Legislation. Almost similar legislations are available in Sweden and France, as such legislations are a norm in the context of European Union for Cross border mobility of EGovernment Service accessibility and Trade.

\subsection{ICT and IT Initiatives on Public Governance in Ethiopia}

\subsubsection{Qualitative Study: Face-Face Interviews on ICT / IT initiatives and Public Sector Reforms in Ethiopia}

From the qualitative study, the various focus areas of E-Governance initiatives and public sector reforms in Ethiopia are identified. The goal of the Ethiopian government (MCIT Ethiopia et al.) is to ensure that all citizens have equal and equitable access to government services and to knowledge and information, and has a commitment to accelerate the development of ICT in order to strengthen the on-going process of sustainable development and poverty reduction as well as good governance and democratic system. In contrast to this goal, in one of the face-face interviews with common citizen it is revealed that, "there exists high level of corruption for even basic services in government offices". In another interview with another citizen, "as citizens we are not aware of the various citizen centric governance decisions, and there is no transparency in policy making".

On the contrary with interviews with public sector experts, they highlight that there are issues with respect to the population literacy level and their knowledge and skill level to utilize ICT based services in Ethiopia. In one of the interviews it is revealed that, "many of the people don't even have an email id or know to use internet, whereas most of them are comfortable with mobile phones and SMS based services". Also in another interview with IT experts, they expressed lack of skilled personnel in ICT domain to handle large scale implementation of E-Governance initiatives.

Language and Cultural barriers have also been cited as major bottlenecks in the interviews with public sector experts and end users. Most of the people in Ethiopia are more comfortable with local language in comparison with foreign language like English. From the interviews conducted with end users in Academics (school, colleges) it is inferred that some of the schools don't even have a proper internet connection, and ICT based education support utilities for Universities and Colleges are yet to reach all regions of Ethiopia. The responses were mixed as the public sector employees in an interview revealed that, "most of the ICT based services are in trial stages in few academic institutions in major cities and regional headquarters and are likely to be rolled out to other institutions shortly". The interviews with end users revealed that E-Greetings facilities, Utility Services like Electricity Bill by SMS, Common Service Centers, Health Initiatives for Epidemic Assistance, Delivery of Digital content in Academics as highly useful. 
The barriers (government and citizen barriers, structural and cultural barriers) to E-Governance implementation (Meijer, 2015: 198), could be easily overcome by new implementation models and frameworks (Government centric focus - (Xiao-Hua, 2009: 128, and Saxena 2005: 498) and latest technology solutions like Cloud Platform and Big Data Analytics. Advanced economies are migrating towards Smart city implementation for efficiency in management of resources, energy, environmental conservation, etc. The concept of a smart city (Clohessy, Acton, \& Morgan, L., 2014: 836) has been identified as not only representing a crucible for technological innovation, a medium for realizing global integration but also as an exemplar response for addressing current and impending global issues (societal, environmental economic and governance).

In Ethiopian context there is a wide gap of Public Governance enabling legal legislations at par with developed and developing countries. For example, in India there is new a legislation namely Right to Information Act, which envisages detailed guidelines on addressing citizen specific queries for transparency of public governance, accountability and disclosure of official government documents on request for scrutiny.

\subsubsection{Quantitative Study: ICT / IT initiatives and Public Sector Reforms in Ethiopia}

From the Cross-sectional questionnaire survey conducted to assess the various E-Governance initiatives in Ethiopia valuable insights are revealed that are crucial for further revamping, re-structuring in public sector reforms. The forthcoming section highlights some of the key findings from the survey data.

\subsubsection{Most preferred E-Governance Initiative in Ethiopia}

From the below gender based choice of most preferred ICT Service (refer Table 5 and Fig. 2) it is inferred that the most preferred of the various E-Governance Initiatives Digital Content Availability in Academics ranks first (11.89\%), followed Common Service Centres (9.47\%), and Citizen Utility Service (8.25\%) in the case of Male Gender. Whereas in the case of Female Gender it is in the order of Common Service Centres (10.68 $\%)$, Digital Content Availability in Academics (9.71\%) and Health Initiatives for Epidemic Control and Assistance $(7.52 \%)$.

In the locality based choice of most preferred ICT Service (refer Table 6 and Fig. 3), Health Initiatives for Epidemic Control and Assistance (6.31\%) is the most preferred for Urban citizens, for Semi Urban it is Utility Services (11.65\%), in Rural it is Common Service Centres (5.83\%) and in Remote Location Government Greetings facilities (5.83\%) seems to have the most reachability. The Implication from the table indicates the importance level and reachability of these initiatives even in remote and rural locations especially since they are simple to understand.

From the Chi-Square Test (refer Table 7) it is inferred that there is no significant relationship between gender and the choice of preferred ICT Service $(\chi=1.536$, Sig $=0.909$, d.f $=5)$. Whereas there exists significant relationship (refer Table 8$)$ between locality and the choice of preferred ICT Service $(\chi=104.004$, Sig $=0.000$, d.f $=15)$.

Table 5. Gender* Most Preferred and Beneficial Government Based ICT / IT Service for Citizens Cross tabulation

\begin{tabular}{|c|c|c|c|c|c|c|c|c|}
\hline \multicolumn{9}{|c|}{ Count } \\
\hline & & \multicolumn{6}{|c|}{ Most Preferred and Beneficial Government Based ICT Service for Citizens } & \multirow[t]{2}{*}{ Total } \\
\hline & & $\begin{array}{c}\text { Delivery of } \\
\text { Digital } \\
\text { Content in } \\
\text { Academics }\end{array}$ & $\begin{array}{c}\text { Health } \\
\text { Information } \\
\text { Assistance }\end{array}$ & $\begin{array}{c}\text { Employment } \\
\text { Assistance }\end{array}$ & $\begin{array}{l}\text { Government } \\
\text { Greetings } \\
\text { Facilities }\end{array}$ & $\begin{array}{c}\text { Citizen } \\
\text { Utility } \\
\text { Services }\end{array}$ & $\begin{array}{c}\text { Common } \\
\text { Service } \\
\text { Centres }\end{array}$ & \\
\hline \multirow{2}{*}{ Gender } & Male & 49 & 29 & 31 & 28 & 34 & 39 & 210 \\
\hline & Female & 40 & 31 & 30 & 28 & 29 & 44 & 202 \\
\hline \multicolumn{2}{|c|}{ Total } & 89 & 60 & 61 & 56 & 63 & 83 & 412 \\
\hline
\end{tabular}




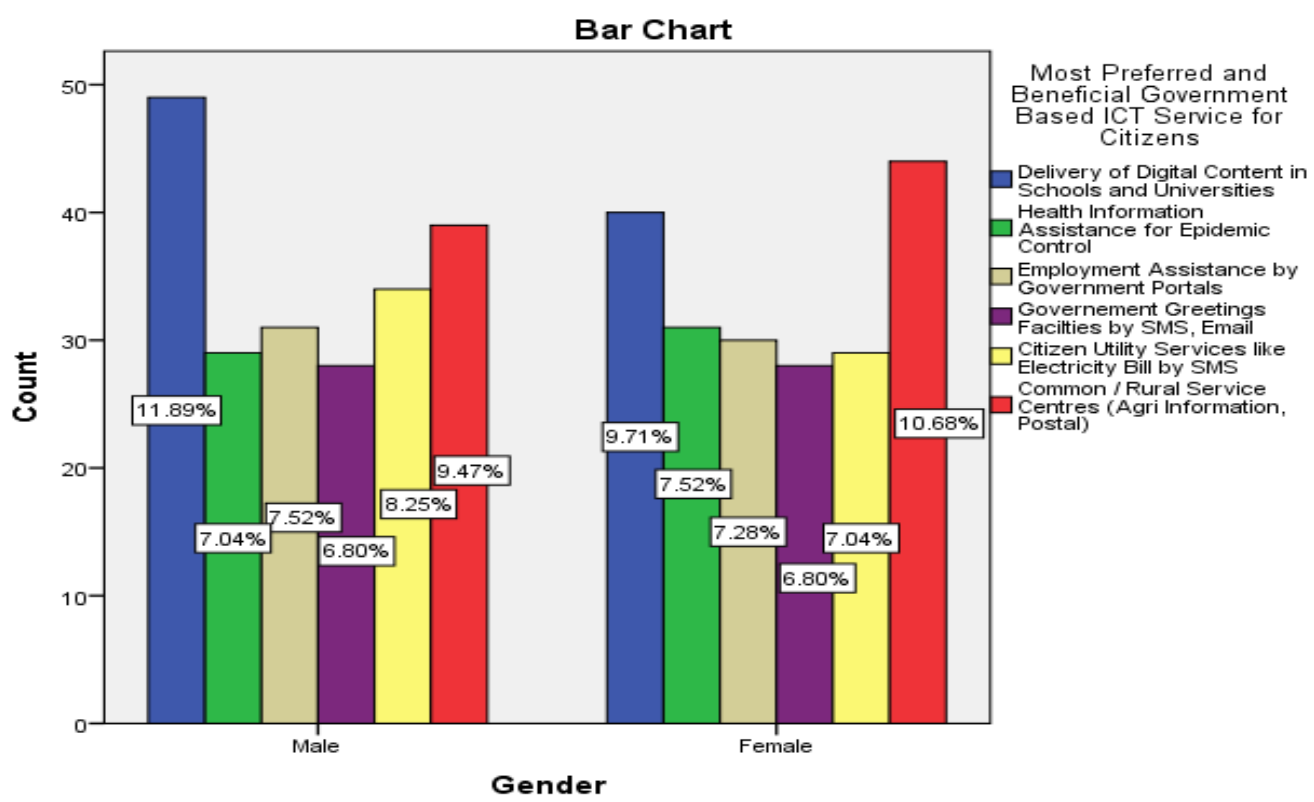

Figure 2. Most Preferred ICT Service Vs Gender Bar Chart

Table 6. Locality * Most Preferred and Beneficial Government Based ICT / IT Service for Citizens Cross tabulation

\begin{tabular}{|c|c|c|c|c|c|c|c|c|}
\hline \multicolumn{9}{|c|}{ Count } \\
\hline & & \multicolumn{6}{|c|}{ Most Preferred and Beneficial Government Based ICT Service for Citizens } & \multirow[t]{2}{*}{ Total } \\
\hline & & \begin{tabular}{|c|} 
Delivery of \\
Digital Content \\
in Academics \\
\end{tabular} & $\begin{array}{c}\text { Health } \\
\text { Information } \\
\text { Assistance } \\
\end{array}$ & $\begin{array}{c}\text { Employment } \\
\text { Assistance }\end{array}$ & \begin{tabular}{|c|} 
Governement \\
Greetings \\
Facilties \\
\end{tabular} & $\begin{array}{c}\text { Citizen } \\
\text { Utility } \\
\text { Services }\end{array}$ & \begin{tabular}{|c} 
Common / \\
Rural Service \\
Centres \\
\end{tabular} & \\
\hline \multirow{4}{*}{ Locality } & Urban & \begin{tabular}{|l|}
17 \\
\end{tabular} & 26 & 20 & 19 & 10 & 9 & 101 \\
\hline & Semi Urban & 21 & 31 & 17 & 21 & 48 & 34 & 172 \\
\hline & Rural & 27 & 1 & 10 & 11 & 5 & 24 & 78 \\
\hline & Remote & 24 & 2 & 14 & 5 & 0 & 16 & 61 \\
\hline \multicolumn{2}{|l|}{ Total } & 89 & 60 & 61 & 56 & 63 & 83 & 412 \\
\hline
\end{tabular}

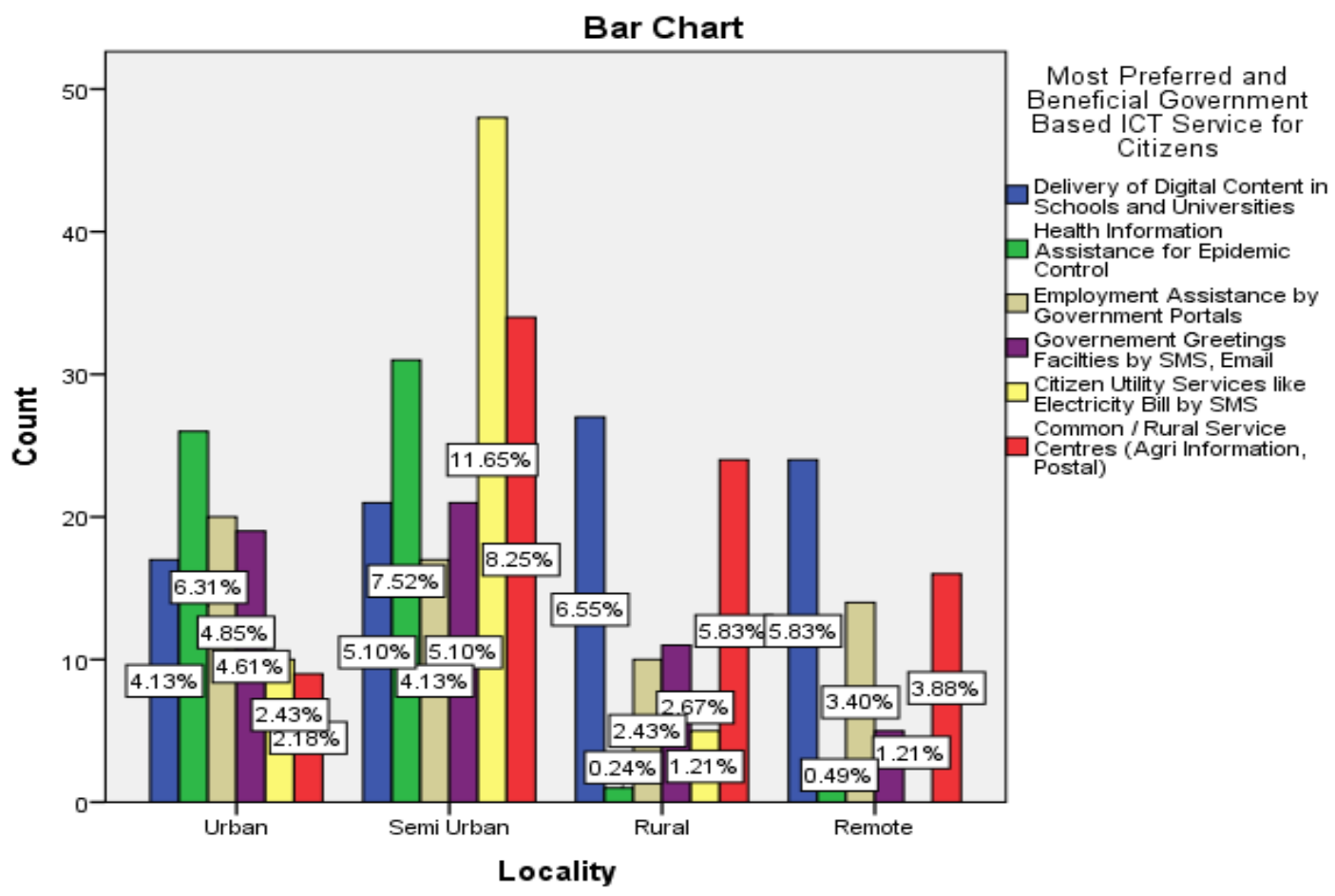

Figure 3. Most Preferred ICT Service Vs Locality Bar Chart 
Table 7. Chi-Square Tests - Gender and The Choice Of Preferred ICT / IT Service

\begin{tabular}{|l|c|c|c|}
\hline & Value & df & Asymp. Sig. (2-sided) \\
\hline Pearson Chi-Square & $1.536 \mathrm{a}$ & 5 & .909 \\
\hline Likelihood Ratio & 1.538 & 5 & .909 \\
\hline Linear-by-Linear Association & .443 & 1 & .506 \\
\hline N of Valid Cases & 412 & & \\
\hline
\end{tabular}

Table 8. Chi-Square Tests - Locality and The Choice of Preferred ICT / IT Service

\begin{tabular}{|l|c|c|c|}
\hline & Value & df & Asymp. Sig. (2-sided) \\
\hline Pearson Chi-Square & $104.004 \mathrm{a}$ & 15 & .000 \\
\hline Likelihood Ratio & 117.856 & 15 & .000 \\
\hline Linear-by-Linear Association & .052 & 1 & .819 \\
\hline N of Valid Cases & 412 & & \\
\hline a. 0 cells (0.0\%) have expected count less than 5. The minimum expected count is 8.29. \\
\hline
\end{tabular}

\subsubsection{Regression Model on Public Sector Reforms in Ethiopia}

From the data surveyed the paper takes into consideration the various ICT initiatives as the independent variable and is assumed to predict the level of public sector reforms (dependent variable) in Ethiopian context in a linear manner. In the study the various public sector ICT initiatives and their reachability are assessed by the awareness level. Similarly, the dependent variable - Public sector reforms is measured by the questions asked on Corruption, Transparency and Citizen participation.

The Table 9 below on Linear Regression indicates that the model best explains the impact of ICT initiatives (Independent variable) on the Public sector reforms (dependent variable) by nearly $50 \%$. $(\mathrm{R}=.701$, $\mathrm{R}$ Square $=$ $0.492, \mathrm{~F}=65.387$, Sig $=.000$ ).

Table 9. Regression Model Summary

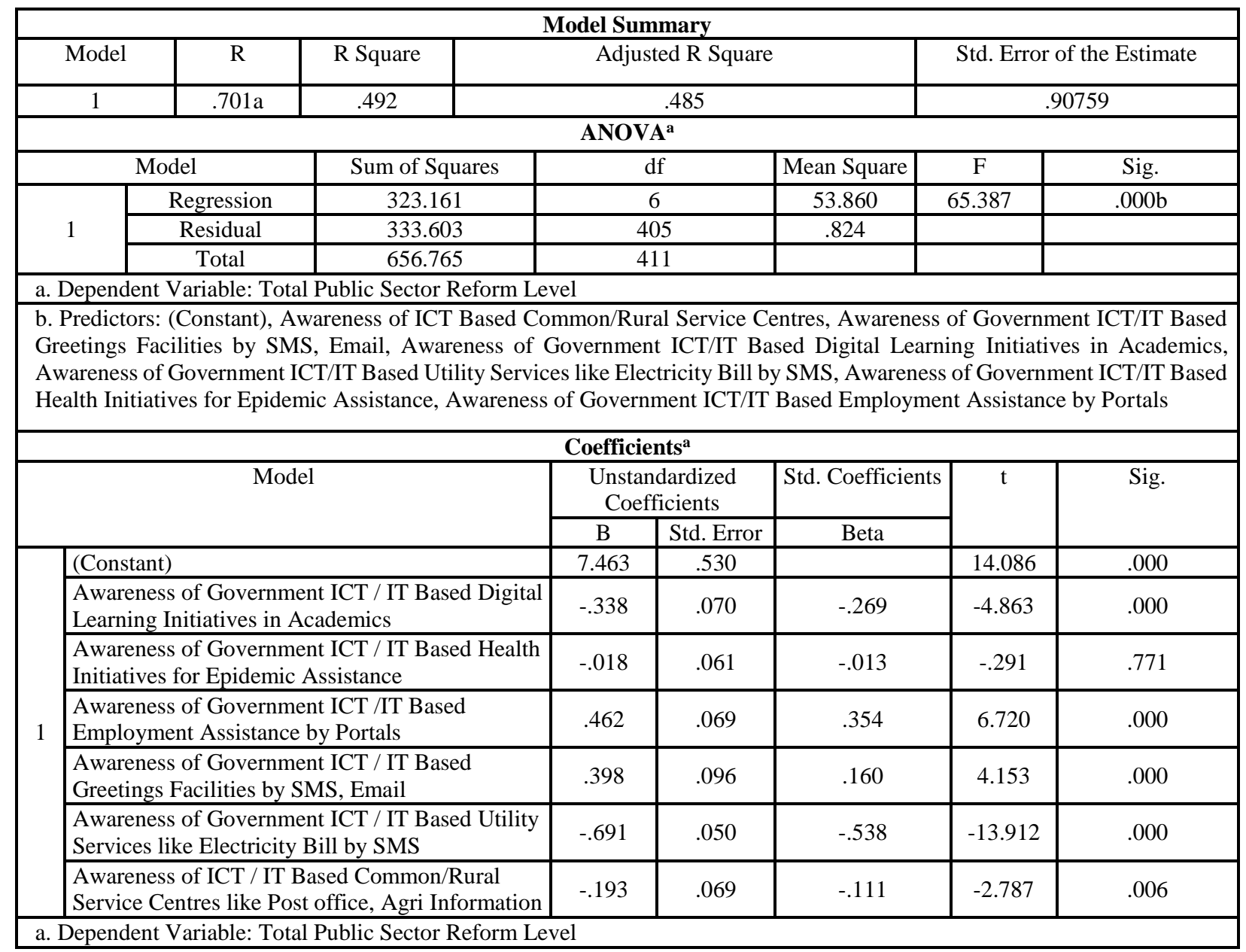


Also from the regression model (refer Table 9), we infer that some of the significant predictors of the public sector reform level in the order of prediction strength (based on standardized coefficient and sigma level) are ICT Based Utility Services $(\beta 1=-.691$, Sig $=0.000)$, ICT Based Employment Assistance by Portals $(\beta 3=$ 0.462 , Sig $=0.000)$, ICT Based Digital Learning Initiatives in Academics $(\beta 2=-.338$, Sig $=0.000)$, ICT Based Greetings Facilities $(\beta 4=0.398$, Sig $=0.000)$ and ICT Based Common/Rural Service Centres $(\beta 5=-$ .193 , Sig $=0.006$ ). The negative values of the Coefficients, can be inferred as lesser availability or awareness of such initiatives in predicting the overall public sector reform level in the case of Ethiopia. In the Linear Regression form it can be expressed as Total Public Sector Reform (Dependent Variable) $=[7.463+(-0.691)$ $\mathrm{x}$ ICT Based Utility Services + (0.462) x ICT Based Employment Assistance by Portals + $(-0.338) \mathrm{x}$ ICT Based Digital Learning Initiatives in Academics + (0.398) x ICT Based Greetings Facilities + $(-0.193) \mathrm{x}$ of ICT Based Common/Rural Service Centres].

\subsubsection{Availability of Innovative E-Governance Initiatives}

The questionnaire survey included some basic questions on the availability of innovative solutions available in Ethiopia at par with Global practices focused on Key ICT Legislations $(\mu=1.9 \pm .666)$, E-Repositories $(\mu$ $=1.93 \pm .512)$, Environment conservation $(\mu=1.91 \pm .613)$, Social Assistance Systems $(\mu=1.81 \pm .736)$, etc. Most of the responses for such questions indicate least availability of such initiatives which can be also inferred as a need for such services in Ethiopian context and the score on each of the items does not even exceeds the midpoint of 2.5 out of the maximum scale point of 5 for each innovative ICT initiative availability (refer descriptive Table 10).

Contrastingly one of the E-Governance initiatives in Ethiopia with most success rate seems to be the availability of ICT, Internet Connectivity and Mobile Infrastructure in Rural and Remote locations $(\mu=4.30$ \pm .612 ). Also from the below ANOVA Tables 11 and 12 it is inferred that the Availability of Internet in Rural and Remote locations is highly significant across gender $(\mathrm{F}=54.7$, Sig $=.000)$ as well as by location $(\mathrm{F}=$ 5.234 , Sig $=.001)$. The visionary leadership and commitment of the Ethiopian Government in building its national ICT infrastructure has paved way for large scale success in this front.

Table 10. Descriptive Statistics (Availability of Innovative ICT / IT Initiatives)

\begin{tabular}{|l|c|c|c|}
\hline & $\mathrm{N}$ & Mean & S.D. \\
\hline $\begin{array}{l}\text { Availability of Key Legislations to enable ICT / IT Based Public } \\
\text { Governance Reforms }\end{array}$ & 412 & 1.90 & .666 \\
\hline $\begin{array}{l}\text { Availability of ICT / IT Based Digital Repository for Centralized Safe } \\
\text { Keeping }\end{array}$ & 412 & 1.93 & .512 \\
\hline $\begin{array}{l}\text { Availability of ICT / IT Based Assistance for Environmental } \\
\text { Conservation, etc. }\end{array}$ & 412 & 1.91 & .613 \\
\hline $\begin{array}{l}\text { Availability of ICT / IT Based Social Assistance System like Subsidy } \\
\text { Application, Tracking }\end{array}$ & 412 & 1.81 & .736 \\
\hline $\begin{array}{l}\text { Availability of Internet and Mobile Connectivity in Rural and Remote } \\
\text { Locations }\end{array}$ & 412 & 4.30 & .612 \\
\hline Valid N (listwise) & 412 & & \\
\hline
\end{tabular}

Table 11. ANOVA (Availability of Internet in Rural and Remote locations -By Gender)

\begin{tabular}{|l|c|c|c|c|c|}
\hline \multicolumn{6}{|c|}{ Availability of Internet and Mobile Connectivity in Rural and Remote Locations } \\
\hline & $\begin{array}{c}\text { Sum of } \\
\text { Squares }\end{array}$ & $\mathrm{df}$ & Mean Square & $\mathrm{F}$ & Sig. \\
\hline Between Groups & 18.113 & 1 & 18.113 & 54.700 & .000 \\
\hline Within Groups & 135.761 & 410 & .331 & & \\
\hline Total & 153.874 & 411 & & & \\
\hline
\end{tabular}

Table 12. ANOVA (Availability of Internet in Rural and Remote locations - By Location)

\begin{tabular}{|l|c|c|c|c|c|}
\hline \multicolumn{6}{|c|}{ Availability of Internet and Mobile Connectivity in Rural and Remote Locations } \\
\hline & $\begin{array}{c}\text { Sum of } \\
\text { Squares }\end{array}$ & $\mathrm{df}$ & Mean Square & $\mathrm{F}$ & Sig. \\
\hline Between Groups & 5.702 & 3 & 1.901 & 5.234 & .001 \\
\hline Within Groups & 148.171 & 408 & .363 & & \\
\hline Total & 153.874 & 411 & & & \\
\hline
\end{tabular}

There has been a steady change in the way in which various developed economies handle the Governance issues focused towards citizen centric and efficient utilization of public resources. In the case of Japan (Kudo, 
2010: 65), it has implemented a series of political and administrative reforms in order to improve accountability. NPM - New Public Management, reforms utilize various strategies to manage public policies, and e-governance is a public policy that directly affects other policies and brings about change. In the case of least developed countries as well as developing economies, public sector reform remains a necessary and ongoing policy objective.

For instance, in Kenya (Hope, 2013: 128) such reforms are being done to overhaul its administrative system to better serve the needs of both government and the citizenry with improved delivery of public services to reduce poverty, improve livelihoods, and sustain good governance. Driven by the belief that e-government is one of the key motors to achieve significant leaps needed for reform, governments are taking wide-ranging initiatives to work better.

Integrated policies and Whole-of-Government (WoG) approaches (UNDESA, 2014) allow governments to pursue sustainable development more effectively, by taking into account the interrelations between 3 dimensions of sustainable development, economic, social and environmental dimensions as well as between the sectors and subsectors addressed by the goals and targets. The 2016 United Nations E-Government Survey offers some insight on the implementation of WoG systems that are seamlessly connected online and the indicators relate to the following (UNDESA, 2012):

$>$ One-stop-shop service platform;

$>$ Advanced search features (since integrated portals typically include an advanced search feature that may index content from dozens of government websites);

Digital ID features that enable different systems to seamlessly exchange information; and

$>$ Online tracking system that permits citizens to check on the status of online transactions.

The need for an integrated approach to policymaking has been expressed in major international agreements, including the 2030 Agenda for Sustainable Development by United Nations, which calls for enhanced policy coherence.

\subsection{Contemporary Trends in Information Technology for E-Governance}

Governments often contract with private sector consulting services to design and implement E-government applications, platforms, and infrastructure. Whenever procuring products or services, E-Government managers should undertake a cost-benefit analysis and give careful consideration to a vendor's track record with deployment and follow-on servicing. Some of these tools and technologies (refer Table 13) include (AFLRA, 2010):

Table 13. E-Governance Tools and Technologies (AFLRA, 2010)

\begin{tabular}{|c|l|l|l|}
\hline S.No. & \multicolumn{1}{|c|}{ E-Governance Tool } & \multicolumn{1}{c|}{ Particulars } \\
\hline 1. & $\begin{array}{l}\text { Geographic Information } \\
\text { Systems (GIS) }\end{array}$ & $\begin{array}{l}\text { Tools that capture, store, analyzes, manage, and present data that are linked to } \\
\text { location(s). GIS systems are used in cartography, remote sensing, land } \\
\text { surveying, public utility management, natural resource management, precision } \\
\text { agriculture, photogrammetry, geography, urban planning, emergency } \\
\text { management, navigation, aerial video, and localized search engines. }\end{array}$ \\
\hline 2. & $\begin{array}{l}\text { Content Management System } \\
\text { (CMS) }\end{array}$ & $\begin{array}{l}\text { Content Management System (CMS) is the Collection of procedures used to } \\
\text { manage work flow in a collaborative environment. These procedures can be } \\
\text { manual or computer-based. In a CMS, data can be defined as nearly anything: } \\
\text { documents, movies, pictures, phone numbers, scientific data, and so forth. }\end{array}$ \\
\hline 3. & $\begin{array}{l}\text { e-Democracy Tools and } \\
\text { Technologies }\end{array}$ & $\begin{array}{l}\text { Include consultation tools, forums, blogs, personalization, email/SMS alerts, } \\
\text { webcasting, chat rooms, social media. }\end{array}$ \\
\hline 5. & $\begin{array}{l}\text { Mobile Phones } \\
\text { Mobile kiosk-based } \quad \text { E- }\end{array}$ & $\begin{array}{l}\text { Mobile phone access is on the rise, and wireless infrastructures hold promise } \\
\text { as a platform for e-Government or "m-Government," as it is sometimes called. } \\
\text { SMS messages can make m-Government especially affordable. }\end{array}$ \\
$\begin{array}{l}\text { One case widely cited is the Mobile SAC project in Brazil's Bahia Province. } \\
\text { Two large, 18-wheel trucks fitted with PCs visit some four hundred townships } \\
\text { in Bahia and stay for three to four days in each site, providing services (issuance } \\
\text { of birth certificates and identity cards). }\end{array}$ \\
\hline
\end{tabular}

From the various Global ICT and IT enabled E-Governance initiatives it is very evident on the usage of contemporary technologies for better Service, handling of large data, speed of access, security, etc. To highlight a few technologies utilized in countries with high maturity level in IT initiatives, Cloud Computing Platform, Big Data Analytics, Diffusion models of Internet access (Rose, 2005: 5), Internet of Things (IoT) 
are the key enablers. Some of the E-governance initiatives are also purely based on Cloud Computing framework replacing the old internet technologies (Mukherjee, \& Sahoo, 2010).

Concepts such as 'smart city', 'intelligent city' and 'knowledge city' build new horizons for cities in undertaking their challenging service functions in an increasingly cost-conscious, competitive and environmentally oriented setting. Smart city notions into green, interconnected, instrumented, open, integrated, intelligent, and innovating layers composing a planning framework. The emerging E-Governance System for Smart City is directed from the point of view of urban domain specialization (Vinod Kumar, 2015: 1) in urban development, urban planning, climate change, carbon accounting, water Governance, energy governance, and public realm and so on.

Smart Cities enablers comprises of Internet of Things technologies and testimonies of different world Smart Cities applications (Madakam \& Ramaswamy, 2015: 1). Collaborative Citizen-Government interaction leads to co-designed user centered innovation services and calls for new governance models. The urban transformation in which citizens are the main "drivers of change" through their empowerment and motivation ensures that the major city challenges can be addressed, including sustainable behavior transformations. (Oliveira \& Campolargo, 2015: 2336). The key dimensions of smart services and the conceptual modeling of smart service platforms through which digital technology is increasingly embedded in social creativity and building of smart cities in urban city planning and resource management, there are benchmark examples and learning from the European context (Anttiroiko, Valkama \& Bailey, 2014: 323).

The 'big data' that are continuously generated by IoT sensors, devices, systems and services are geo-tagged or geo-located. The World Health Organization (WHO) Healthy Cities Network and associated national networks have hundreds of member cities around the world that could benefit from, and harness the power of, IoT to improve the health and well-being of their local populations (Kamel Boulos \& Al-Shorbaj, 2014: 10).

\subsection{Conclusion}

From the paper one of the major conclusion is that, the developed countries have attained higher levels of maturity in E-Governance implementation and public sector reforms. And the citizens of such countries have already starting reaping the benefits by the way of better public service, transparency in governance and financial accountability, and stakeholder participation in policy formulation and governance. Though there are no generalized conceptual frameworks of E-Governance at the Global level, but there is suitability of customized models (e.g. EXPGOV Framework) for rapidly changing scenarios in each implementation perspective due to changing technology and needs. From the latest UN E-Government survey (UNDESA, 2016) and Case insights of India and Europe, a wide array of benchmark ICT and IT enabled initiatives and services suiting to each country specific needs are identified.

The discussion on the Ethiopian ICT policy and strategy throws light on the commitment level and focus areas of public reforms and E-Governance orientation. The initial qualitative study conducted with various stakeholders of E-Governance paved way for focusing on key enablers of E-Governance and as starting point to identify the variables of the quantitative study to assess the awareness level of E-governance in Ethiopia. Also it is inferred that the E-Governance initiatives of Ethiopia are broadly categorized under Infrastructure building, ICT based applications, Policy, Standards, Guidelines and HRD.

The quantitative study on the awareness level of ICT / /IT initiatives \& Public Sector Reforms in Ethiopia confirms the high success rate of ICT Infrastructure implementation, as most of the surveyed respondents agree on availability of ICT, Internet Connectivity and Mobile Infrastructure even in Rural and Remote locations. Whereas, there is still a long way to go in delivering innovative ICT based E-governance services and solutions at par with developed countries. From the regression model, we infer that some of the significant predictors on public sector reforms in Ethiopia in the order of prediction strength are ICT / IT Based Utility Services, Employment Assistance by Portals, Digital Learning Initiatives in Academics, Greetings Facilities and Common/Rural Service Centers.

\section{References}

1. AFLRA (2010). Association of Finnish Local and Regional Authorities. Strengthening e-Governance in the North-South Local Government Co-operation Programme. Helsinki, Finland. Retrieved May 5, 2017 from: http://shop.kunnat.net/uploads/sisalto_meyaki_verkkoon.pdf. 
2. Anttiroiko, A. V., Valkama, P., \& Bailey, S. J. (2014). Smart cities in the new service economy: Building platforms for smart services. AI and Society, 29(3), 323-334. Retrieved April 22, 2017 from: https://doi.org/10.1007/s00146-013-0464-0.

3. Backus, M. (2001) E-Governance and Developing Countries, Introduction and examples, Research Report, No. 3, April 2001.

4. Beri, G C. (2008). Marketing Research, 4e. New Delhi: Tata McGraw Hill Publishing Company.

5. Bingham, L. B., Nabatchi, T. and O'Leary, R. (2005), The New Governance: Practices and Processes for Stakeholder and Citizen Participation in the Work of Government. Public Administration Review, 65, 547558. doi:10.1111/j.1540-6210.2005.00482.x.

6. Bryson, J. M., Crosby, B. C., \& Bloomberg, L. (2014). Public value governance: Moving beyond traditional public administration and the new public management. Public Administration Review, 74(4), 445-456. Accessed (4th April 2017) from: https://doi.org/10.1111/puar.12238.

7. Clift, S. (2003) E-Governance to E-Democracy: Progess in Australia and New Zealand toward InformationAge Democracy http://www.publicus.net/articles/edempublicnetwork.html.

8. Clohessy, T., Acton, T., \& Morgan, L. (2014). Smart city as a service (SCaaS): A future roadmap for egovernment smart city cloud computing initiatives. In Proceedings - 2014 IEEE/ACM 7th International Conference on Utility and Cloud Computing, UCC 2014 (pp. 836-841). Retrieved April 22, 2017 from: https://doi.org/10.1109/UCC.2014.136.

9. Digital India (2015). Digital India - Programme Pillars. Retrieved April 21, 2017 from: http://digitalindia.gov.in/content/programme-pillars.

10.Ebrahim Z., \& Irani Z. (2005). E-government adoption: architecture and barriers. Business Process Management Journal, 11(5), 589-611. Retrieved April 22, 2017, from Emerald Group Publishing Limited ISSN 1463-7154.

11.European Union (2016). E-Government in Ireland. European Commission. ISA Programme, pp.18-19. Retrieved https://joinup.ec.europa.eu/sites/default/files/ckeditor_files/files/eGovernment\%20in\%20Ireland\%20\%20February\%202016\%20-\%2018 00\%20-\%20v2 00.pdf.

12.El-Haddadeh, R., Weerakkody, V., \& Al-Shafi, S. (2013). The complexities of electronic services implementation and institutionalisation in the public sector. Information and Management, 50(4), 135-143. Retrieved April 4, 2017 from: https://doi.org/10.1016/j.im.2013.02.005.

13.European Commission (2010). European Commission, Joint Research Centre, Institute for Prospective Technological Studies, Concept Paper of the Exploratory Research on emerging ICT-enabled governance models in EU cities, EXPGOV Framework. Available at: http://is.jrc.ec.europa.eu/pages/EAP/documents/EXPGOVD4ConceptPaperDraftV1.0-22032010.pdf.

14.Field, A. P. (2009). Discovering statistics using SPSS. London, England : SAGE.

15.Guma, P. K. (2013). Public-Sector Reform, E-Government and the Search for Excellence in Africa: Experiences from Uganda. Electronic Journal of E-Government, 11(2), 240-251.

16.Hair, J., Black, W., Babin, B., Anderson, R., \& Tatham, R. (2006). Multivariate data analysis (6th ed.). Uppersaddle River, N.J.: Pearson Prentice Hall.

17.Helen, D. (2016). From New Public Management to New Public Governance: The implications for a 'new public service'. In John R. Butcher, David J. Gilchrist, The Three Sector Solution: Delivering public policy in collaboration with not-for-profits and business, Canberra: ANU Press, pp. 41-60.

18.Hope, Sr., K. R. (2013). Managing the Public Sector in Kenya: Reform and Transformation for Improved Performance. Journal of Public Administration and Governance, 2(4), 128-143. Retrieved April 4, 2017 from: https://doi.org/10.5296/jpag.v2i4.2751.

19.Kamel Boulos, M. N., \& Al-Shorbaji, N. M. (2014). On the Internet of Things, smart cities and the WHO Healthy Cities. International Journal of Health Geographics, 13(1), 10. Retrieved April 22, 2017 from: https://doi.org/10.1186/1476-072X-13-10.

20.Kannabiran, G., Xavier, M. J., \& Banumathi, T. (2008). E-Governance and ICT Enabled Rural Development in Developing Countries: Critical Lessons from RASI Project in India. International Journal of Electronic Government Research, 4(3), 1-19.

21.Kudo, H. (2010). E-governance as strategy of public sector reform: peculiarity of Japanese IT policy and its institutional origin. Financial Accountability \& Management, 26(1), 65-84. Retrieved April 4, 2017 from: https://doi.org/10.1111/j.1468-0408.2009.00491.x.

22.Kulshreshtha, P. (2008). Public sector governance reform: the World Bank's framework. International Journal of Public Sector Management, 21(5), 556-567. Retrieved April 4, 2017 from: https://doi.org/DOI $\underline{10.1108 / 09513550810885831 .}$ 
23.Madakam, S., \& Ramaswamy, R. (2015). 100 New Smart Cities. Information Technology: Towards New Smart World (NSITNSW), 2015 5th National Symposium on, 1-6. Retrieved April 22, 2017 from: https://doi.org/10.1109/NSITNSW.2015.7176407.

24.MCIT Ethiopia. (2011). ICT Sector Development in Ethiopia. Retrieved April 22, 2017 from: http://www.mcit.gov.et/web/english/ict-sector-development-in-ethiopia.

25.Meijer, A. (2015). E-governance innovation: Barriers and strategies. Government Information Quarterly, 32(2), 198-206. Retrieved April 23, 2017 from: https://doi.org/10.1016/j.giq.2015.01.001.

26.Misuraca, G., Alfano, G., \& Viscusi, G. (2011). Interoperability challenges for ICT-enabled governance: Towards a pan-European conceptual framework. Journal of Theoretical and Applied Electronic Commerce Research, 6, 95-111. Retrieved April 23, 2017 from: http://doi.org/10.4067/S0718-18762011000100007.

27.Nargundkar, R. (2003). Marketing Research, New Delhi, Tata McGraw-Hill Publishing Co. Ltd., p.220.

28. Oliveira, Á., \& Campolargo, M. (2015). From smart cities to human smart cities. In Proceedings of the Annual Hawaii International Conference on System Sciences (Vol. 2015-March, pp. 2336-2344). Retrieved April 23, 2017 from: https://doi.org/10.1109/HICSS.2015.281.

29.Osborne S. P. (2006). The new public governance? Public Management Review, 8(3), 377-87.

30.Peters, J. (2012). Neoliberal convergence in North America and Western Europe: Fiscal austerity, privatization, and public sector reform. Review of International Political Economy, 19 (June 2015), 208235. Retrieved April 23, 2017 from: https://doi.org/10.1080/09692290.2011.552783.

31.Pollitt, C., Thiel, S. van, \& Homburg, V. (2007). New public management in Europe. Management Online Review, (October), 1-7. Retrieved April 4, 2017 from: https://doi.org/10.1057/9780230625365.

32.Rose, R. (2005). A Global Diffusion Model of E-Governance. Journal of Public Policy, 25(1), 5-27. Retrieved April 23, 2017 from: https://doi.org/10.1017/S0143814X05000279.

33.Saxena, K. B. C. (2005). Towards excellence in e-governance. International Journal of Public Sector Management, 18(6), 498-513. Retrieved April 23, 2017 from: https://doi.org/10.1108/09513550510616733.

34.UNDESA (2012). UN Department of Economic and Social Affairs. Big Data for Development: Challenges and Opportunities. April $\quad$ Retrieved 23, 2017 from: http://www.unglobalpulse.org/sites/default/files/BigDataforDevelopment-GlobalPulseMay2012.pdf.

35.UNDESA. (2014). UN Department of Economic and Social Affairs. United Nations E-Government Survey 2014. E-Government for The Future We Want. Retrieved April 23, 2017 from: https://publicadministration.un.org/egovkb/portals/egovkb/documents/un/2014-survey/egov_complete_survey-2014.pdf.

36.UNDESA. (2016). UN Department of Economic and Social Affairs (2016). United Nations E-Government Survey 2016, E-Government in Support of Sustainable Development. Retrieved April 23, 2017 from: http://workspace.unpan.org/sites/Internet/Documents/UNPAN96407.pdf.

37.United Nations (2011). E-Government Initiatives in Ethiopia. The African E-Leadership Meeting, Dar es Salaam, Tanzania. $\quad$ Retrieved April 22, 2017 from: http://www.unpan1.un.org/intradoc/groups/public/documents/un/unpan046467.pdf.

38.Vinod Kumar, T. M. (2015). E-Governance for Smart Cities. In T. M. Vinod Kumar (Ed.), E-Governance for Smart Cities (pp. 1-43). Singapore: Springer Singapore. http://doi.org/10.1007/978-981-287-287-6 1.

39.Vries, M. De, \& Nemec, J. (2013). Public sector reform: an overview of recent literature and research on NPM and alternative paths. International Journal of Public Sector Management, 26(1), 4-16. Retrieved April 4, 2017 from: https://doi.org/10.1108/09513551311293408.

40.Xiao-Hua, L. (2009). New perspective for e-governance performance. In 2009 International Conference on Management of e-Commerce and e-Government, ICMeCG 2009 (pp. 128-132). Retrieved April 23, 2017 from: https://doi.org/10.1109/ICMeCG.2009.96.

41.Zwahr, T., Finger, M., \& Mueller, P. (2005). More than Digitisation - The Transformative Potential of EGovernance: An Exploratory Case Study. Proceedings of the 38th Hawaii International Conference on System Sciences - 2005, 0-7695-2268-8/05/ IEEE, 1-9. 